\title{
Relevance of apple consumption for protection against oxidative damage induced by hydrogen peroxide in human lymphocytes
}

\author{
Francesca Maffei ${ }^{1 *}$, Andrea Tarozzi $^{1}$, Fabio Carbone ${ }^{1}$, Alessandra Marchesi ${ }^{1}$, Silvana Hrelia ${ }^{2}$, \\ Cristina Angeloni ${ }^{2}$, Giorgio Cantelli Forti $^{1}$ and Patrizia Hrelia ${ }^{1}$ \\ ${ }^{1}$ Department of Pharmacology, University of Bologna, Via Irnerio 48, 40126 Bologna, Italy \\ ${ }^{2}$ Department of Biochemistry 'G. Moruzzi', University of Bologna, Via Irnerio 48, 40126 Bologna, Italy
}

(Received 21 August 2006 - Revised 10 October 2006 - Accepted 20 November 2006)

\begin{abstract}
In a single-dosing crossover study, we investigated the ability of apple fruit consumption to protect human lymphocytes against peroxide-induced damage to DNA. Six healthy, non-smoking male volunteers were placed for $2 \mathrm{~d}$ on an antioxidant-poor (AP) diet. After $48 \mathrm{~h}$ of AP diet, the volunteers were required to consume a homogenate obtained from $600 \mathrm{~g}$ of red delicious unpeeled apples or water (500 ml); blood samples were collected $0,3,6$ and $24 \mathrm{~h}$ post-consumption. To evaluate whether the apple intake was sufficient to restore resistance of DNA to oxidative damage, for each subject at any time point the plasma total antioxidant activity, reactive oxygen species (ROS) formation and induction of micronuclei $(\mathrm{MN})$ in isolated lymphocytes following hydrogen peroxide $\left(\mathrm{H}_{2} \mathrm{O}_{2}\right)$ treatment were measured. Results indicated a significant inhibition (58\%, $\mathrm{P}<0.05)$ of $\mathrm{H}_{2} \mathrm{O}_{2}$-induced $\mathrm{MN}$ frequency in the plasma samples collected at $3 \mathrm{~h}$ after apple consumption, as compared with plasma samples collected at $0 \mathrm{~h}(4.17$ (SD 1.83) v. 9.85 (SD 1.87) MN/1000 binucleated (BN) cells, respectively). A gradual return towards the value observed at $0 \mathrm{~h}$ was recorded starting from 6 to $24 \mathrm{~h}$. MN frequency induced by $\mathrm{H}_{2} \mathrm{O}_{2}$ was significantly influenced by plasma total antioxidant activity $(r=-0.95, P<0.05)$ and by the increase of intracellular ROS formation $(r=0 \cdot 88, P<0 \cdot 05)$. These findings suggest that the consumption of whole apple provides a useful dietary source of active scavengers to protect cells and tissue from oxidative stress and related DNA injury.
\end{abstract}

Phytochemicals: Plasma antioxidant activity: Reactive oxygen species: Genetic damage

A considerable body of evidence indicates that the risk of degenerative diseases is considerably lower in people who consume antioxidant-rich fruits and vegetables and it has been proposed that extra health benefits may derive from aboveaverage intake of these compounds (Peto et al. 1981; Block et al. 1992; Hertong et al. 1995; Steinmetz et al. 1996; WCRF/AICR, 1997; Terry et al 2001; Bazzano et al. 2002; Knekt et al. 2002; Collins et al. 2004). Food components can modulate the maintenance of the oxidant-antioxidant balance and may thereby influence the health status. Oxidative reactions are of major significance in human pathophysiology, and oxidative stress has been linked to diseases such as atherosclerosis, diabetes, cancer and tissue damage in rheumatoid arthritis (Hertog et al. 1993, 1995; Knekt et al. 1996; Scalbert et al. 2005). In the field of cancer, it is accepted that both genotoxic and non-genotoxic carcinogens act through the induction of DNA oxidative damage (Ames et al. 1995; Duthies et al. 1996; Collins \& Ferguson, 1998).

Epidemiological studies have shown only an association between total intake of fruit and vegetables and beneficial effects, with limited evidence linked to individual phytochemicals. Large-scale intervention trials have failed to show decreased cancer risks following selective vitamin and antioxidant supplementation (Omenn et al. 1996; Jacobson et al. 2000; Galati \& O'Brien, 2004). These results confirm that the dietary intake of antioxidant-rich food (rather than single antioxidant supplementation) can be a means of improving the health of individuals and of preventing or reducing the risk of chronic diseases. The antioxidant activity of pure antioxidant compounds has been studied in cell cultures, but human studies are needed to evaluate the biological effects of the complex mixture in which they occur in real food.

Apples are one of the main sources of dietary antioxidants, the polyphenolic compounds, in the Western diet (Art et al. 2001; Boyer \& Liu, 2004). Gallus et al. (2005) found a consistent inverse association between apple consumption and risk of various cancers. Fresh apples have been shown to provide greater levels of antioxidants and anticancer activity in vitro than are provided by dietary supplementation of vitamin C (Eberhardt et al. 2000), suggesting that phytochemicals (phenolic acids and flavonoids) other than ascorbic acid interact in a synergistic manner to provide biological effects. Apple polyphenol extracts were demonstrated to prevent damage to human gastric epithelial cells in vitro and to rat gastric mucosa in vivo (Graziani et al. 2005). Assessment of antioxidant bioactivity in vitro, measured in terms of

Abbreviations: AP, antioxidant-poor; BN, binucleated; DCFH-DA, 2',7'-dichlorodihydrofluorescein diacetate; HBSS, Hank's balanced salt solution; MN, micronuclei; ROS, reactive oxygen species; TEAA, Trolox equivalent antioxidant activity.

* Corresponding author: Dr Francesca Maffei, fax, +39051 248862, email francesca.maffei@unibo.it 
intracellular antioxidant, cytoprotective and antiproliferative activity in human colon carcinoma cells, showed strong, time-related decreases for all three parameters by whole apple homogenates (Hrelia et al. 2003; Tarozzi et al. 2004). Whether apples have a protective effect against oxidative stress-related injury in humans is still unproven.

Therefore, we performed a single-dosing crossover study to investigate the ability of whole apple fruit to prevent hydrogen peroxide-induced damage to DNA in humans. An ex vivo approach was adopted - utilising plasma and lymphocytes from peripheral blood of healthy volunteers - to study total plasma antioxidant activity alongside exogenously induced reactive oxygen species (ROS) formation and DNA damage in separated lymphocytes.

\section{Materials and methods}

\section{Subjects and study design}

Six healthy, non-smoking male volunteers aged 29.7 (SD 4.5) years (range: $25-37$ years) with a mean BMI of 23.5 (SD 2.0) $\mathrm{kg} / \mathrm{m}^{2}$ (range: $21 \cdot 6-27.2 \mathrm{~kg} / \mathrm{m}^{2}$ ) participated in a single-dosing crossover study, which was performed according to the Declaration of Helsinki. All participants were informed of the study aims and provided written informed consent. Each individual was interviewed in-depth by a specialised physician who filled in a structured questionnaire to exclude the following characteristics: exposure to diagnostic/therapeutic X-rays or chemotherapeutic drugs in the previous 3 months; current use of nutritional supplements, deficient diet or peculiar dietary habits; past/present smoking status; chronic or metabolic disease; and occupational exposure to genotoxic compounds. All volunteers had a normal-caloric diet, and were regular consumers of all the food categories (vegetables, fruit, meat, milk, cheese, eggs, pasta and bread). They were moderate consumers of wine and/or beer ( $<11$ per week), but did not consume spirits.

The experimental protocol followed a single-dosing crossover design as summarised in Fig. 1. The volunteers were initially required to provide a blood sample after an overnight fast, following which they were placed for $2 \mathrm{~d}$ on an antioxidant-poor (AP) diet, since the antioxidant effects of apples may be more easily observed when the status in other antioxidants is low. The foods that were allowed in the AP diet are

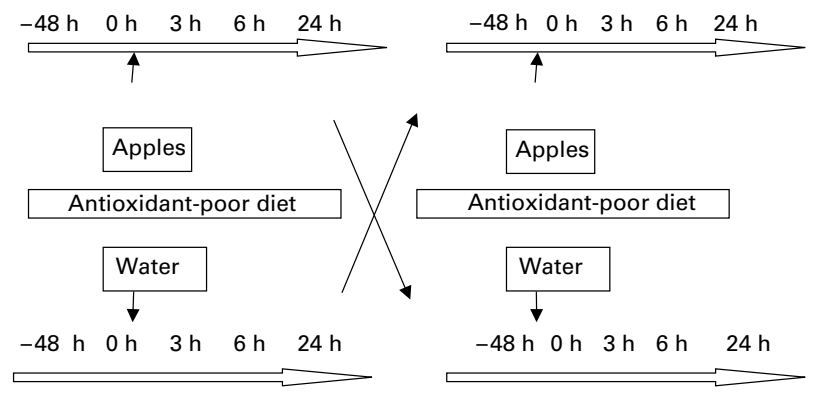

7 days normal diet

Fig. 1. Intervention crossover design showing time, in hours, relative to apples or placebo drink. listed in Table 1. After $48 \mathrm{~h}$ of AP diet, a second fasted blood sample was taken. Ten minutes later, subjects were randomly assigned (three subjects per group) to consume either a homogenate obtained from $600 \mathrm{~g}$ of fresh red delicious unpeeled apples (the equivalent of five pieces of fruit, obtained from a local market) or $500 \mathrm{ml}$ of water. For the preparation of the homogenate, unpeeled apples were cut into small pieces, briefly blended, and then the homogenate was immediately consumed by the subjects. The amount of apples selected for the study is a large portion, that is not always easy to eat in a single intake; however, the homogenate allowed a quick and easy consumption of apples in large quantities. Further blood samples were taken 3,6 and $24 \mathrm{~h}$ after the drink, while still on the AP diet. Volunteers then returned to their normal diets for a 1 week wash-out period, after which the intervention was repeated with a crossover in the type of drink taken.

\section{Blood processing}

Venous peripheral blood samples were collected by medical workers in heparinised tubes and were coded. Processing and scoring of the samples were performed blind and concurrently. At the end of the study, the data from the questionnaire were linked to the code number for data analysis. Within $30 \mathrm{~min}$ of collection, blood samples were centrifuged $\left(1500 \mathrm{~g}, 15 \mathrm{~min}, 4{ }^{\circ} \mathrm{C}\right)$ to obtain the plasma and buffy-coat from each sample. Each plasma sample was removed and divided into two aliquots: one for $\mathrm{H}_{2} \mathrm{O}_{2}$ challenge and the other for biochemical analysis. The buffy coat was mixed with physiological solution $(0.09 \% \mathrm{NaCl})$, and carefully layered onto a Hystopaque 1077 gradient (Sigma-Aldrich, St Louis, MO, USA) to isolate the peripheral lymphocytes. After centrifugation for $30 \mathrm{~min}$ at 1800 r.p.m., the lymphocytes were collected, washed (with RPMI 1640 medium), centrifuged and divided into two aliquots: one for micronuclei $(\mathrm{MN})$ assay, the other to determine the ROS formation induced in vitro by $\mathrm{H}_{2} \mathrm{O}_{2}$.

\section{Determination of plasma total antioxidant activity}

Total antioxidant activity - a marker of plasma antioxidant status - was measured as reported by Re et al. (1999) This method is based on the ability of the antioxidant molecules

Table 1. Details of food and drink restrictions during the antioxidantpoor diet

\begin{tabular}{ll}
\hline Foods allowed & \multicolumn{1}{c}{ Foods not allowed } \\
\hline Beef, pork, chicken, ham & All fruits (fresh, fried or stewed) \\
Cheese & All vegetables, legumes \\
White bread & Nuts \\
White rice (not brown) & Fruit or vegetable juice \\
Ordinary (not whole meal) pasta & Coca-Cola, Fanta and all fizzy drinks \\
Butter & Wine, beer, alcoholics drinks \\
Water, milk & Tea and coffee \\
& Chocolate and chocolate drinks \\
& Jams, marmalades \\
& Tomato sauce, chutney, curry, pepper \\
& All breakfast cereals \\
& Cakes \\
\hline
\end{tabular}


present in plasma to reduce the radical cation of $2,2^{\prime}$-azinobis-(3-ethylbenzothiazoline-6-sulphonic acid (ABTS), determined by the decolorization of $\mathrm{ABTS}^{+}$and measured as quenching of absorbance at $740 \mathrm{~nm}$. Values obtained for each sample were compared with the concentration-response curve of a standard Trolox solution and expressed as Trolox equivalent antioxidant activity (TEAA) in mmol/l.

\section{Determination of intracellular ROS formation}

Formation of intracellular ROS was determined using the fluorescent probe $2^{\prime}, 7^{\prime}$-dichlorodihydrofluorescein diacetate (DCFH-DA), as previously reported (Rosenkranz et al. 1992). Briefly, freshly isolated human lymphocytes were suspended at a concentration of $1 \times 10^{6}$ cells/ml in $2 \mathrm{ml}$ of Hank's balanced salt solution (HBSS) and incubated for $30 \mathrm{~min}$ with DCDHFDA $(10 \mu \mathrm{mol} / 1)$ at $37^{\circ} \mathrm{C}$ in the dark in a multiwell plate. After removal of DCFH-DA, the lymphocytes were washed with phosphate-buffered saline and incubated with $\mathrm{H}_{2} \mathrm{O}_{2}$ $(100 \mu \mathrm{mol} / \mathrm{l})$ in HBSS for $30 \mathrm{~min}$ at $37^{\circ} \mathrm{C}$. The fluorescence of the cells from each well was measured using $485 \mathrm{~nm}$ excitation and $535 \mathrm{~nm}$ emission with a microplate spectrofluorometer (VICTOR3 V ${ }^{\mathrm{TM}}$ Multilabel Counter, Perkin Elmer, Wellesley, MA, USA). The values were expressed as the percentage increase of intracellular oxidative species evoked by exposure to $\mathrm{H}_{2} \mathrm{O}_{2}$ and calculated by the formula $\left[100 \times\left(F_{\mathrm{t}}-F_{\mathrm{nt}}\right) / F_{\mathrm{nt}}\right]$, where $F_{\mathrm{t}}=$ fluorescence of treated lymphocytes and $\mathrm{F}_{\mathrm{nt}}=$ fluorescence of non-treated lymphocytes.

\section{MN assay}

The cytokinesis-block $\mathrm{MN}$ assay in human lymphocytes is a multi-end-point assay that can measure DNA damage (chromosome damage) after oxidative stress, along with the morphological evaluation of necrosis and apoptosis, in cells that have completed nuclear division (Crott \& Fenech, 1999; Fenech et al. 1999). MN are efficiently expressed in dividing cells when chromosome breaks are induced by hydroxyl radicals. The induced chromosome breaks lag behind at anaphase in dividing cells and are subsequently packaged within nuclear membranes to produce MN.

To measure baseline MN frequencies, aliquots of lymphocytes $\left(1 \times 10^{6}\right)$ collected and isolated at each time point were cultured directly in an RPMI 1640 medium $(5 \mathrm{ml})$ containing $15 \%$ fetal calf serum, $1 \%$ phytohaemmaglutinin, L-glutamine $1 \mathrm{mmol} / \mathrm{l}, 100 \mathrm{U}$ of penicillin and $100 \mu \mathrm{g} / \mathrm{ml}$ streptomycin (all purchased from Sigma-Aldrich). Cultures were incubated with $5 \% \mathrm{CO}_{2}$ at $37^{\circ} \mathrm{C}$ for $72 \mathrm{~h}$.

To test the effect of the $\mathrm{H}_{2} \mathrm{O}_{2}$ challenge, lymphocytes $\left(1 \times 10^{6}\right)$ from each collection were added to the same donor's plasma $(1 \mathrm{ml})$ taken at the same time point, stored at $37^{\circ} \mathrm{C}$, and then incubated for $30 \mathrm{~min}$ to allow metabolites in plasma and cells to equilibrate. Cells were then treated with either (1) $\mathrm{H}_{2} \mathrm{O}_{2}(700 \mu \mathrm{mol} / \mathrm{l})$ from a freshly prepared stock solution in HBSS; or (2) the same volume of HBSS without $\mathrm{H}_{2} \mathrm{O}_{2}$.

The selection of the dose of $700 \mu \mathrm{mol} / 1 \mathrm{H}_{2} \mathrm{O}_{2}$ was based on preliminary dose-response studies with/without $\mathrm{H}_{2} \mathrm{O}_{2}$ challenge (dose range: from 100 to $1000 \mu \mathrm{mol} / \mathrm{l}$ ). It has been found that $700 \mu \mathrm{M}$ induced a significant increase of $\mathrm{MN}$ frequency in the lymphocytes from each volunteer without causing cytotoxicity or markedly diminishing the frequency of the $\mathrm{BN}$ cells used for $\mathrm{MN}$ scoring (data not shown). Furthermore, the dose of $\mathrm{H}_{2} \mathrm{O}_{2}(700 \mu \mathrm{mol} / \mathrm{l})$ has been previously used by Fenech et al. (1997). A higher dose of $\mathrm{H}_{2} \mathrm{O}_{2}$ was used in these experiments because the lymphocytes were much less sensitive to this agent when incubated with plasma relative to incubation in HBSS selected for the determination of intracellular ROS formation.

After $30 \mathrm{~min}$, the lymphocytes were transferred into the culture medium used for $\mathrm{MN}$ measurement (described above) and incubated with $5 \% \mathrm{CO}_{2}$ at $37^{\circ} \mathrm{C}$ for $72 \mathrm{~h}$.

In all cultures, cytochalasin-B (Sigma-Aldrich) was added (final concentration $6 \mathrm{mg} / \mathrm{ml}$ ) for the last $28 \mathrm{~h}$. Cells were then collected and treated with a mild hypotonic treatment (RPMI1640 medium-distilled water, 50:50 v/v) and fixed with a mixture of methanol/glacial acetic acid, as previously described (Fenech \& Morley, 1985). The slides were prepared by cytocentrifuge, air-dried, and stained by conventional May-Grünwald Giemsa staining (Sigma-Aldrich).

In accordance with standard criteria, $\mathrm{MN}$ analysis was performed on coded slides by scoring $1000 \mathrm{BN}$ lymphocytes for each of the two duplicate cultures. Cell division frequency is shown as the percentage of viable (non-apoptotic/non-necrotic) cells that are binucleated $(\% \mathrm{BN})$. Apoptosis and necrosis are expressed as percentages of the total cell number. Total cell numbers included mononuclear cells, BNs, other multinucleated cells, apoptotic and necrotic cells (Fenech et al. 1999). All assays were performed in duplicate cultures.

\section{Statistical analysis}

Values are means and standard deviations. Paired data $t$ test was performed to analyse the time-response data. Pearson's regression analysis was used to evaluated the influence of the plasma total antioxidant activity and $\mathrm{H}_{2} \mathrm{O}_{2}$-induced intracellular oxidative species formation on $\mathrm{MN}$ frequency induced by $\mathrm{H}_{2} \mathrm{O}_{2}$. Statistical analysis was conducted using GraphPAD Prism-3.02.

\section{Results}

Effect of apple consumption on plasma total antioxidant activity

As reported in Fig. 2, an AP diet significantly reduced the plasma total antioxidant activity in terms of TEAA (appleassigned subjects, 1.69 (SD0.05) (-48h) v. 1.59 (SD 0.04) $\mathrm{mmol} / \mathrm{l}(0 \mathrm{~h})$; water-assigned subjects, 1.68 (SD 0.04) (-48 h) v. 1.58 (SD 0.04) $\mathrm{mmol} / \mathrm{l}(0 \mathrm{~h})$; all $P<0.05)$. Subsequently, after ingestion of water, TEAA values at 3, 6 and $24 \mathrm{~h}$ remained similar to those found at $0 \mathrm{~h}$. In contrast, ingestion of apples led to significantly increased plasma TEAA at both $3 \mathrm{~h}(1.64$ (SD 0.02) mmol/l; $P<0.05$ v. $0 \mathrm{~h}$ ) and $6 \mathrm{~h}(1.64$ (SD 0.03) $\mathrm{mmol} / \mathrm{l} ; P<0.05$ v. $0 \mathrm{~h}$ ). Plasma antioxidant activity $24 \mathrm{~h}$ after apple intake returned toward the values observed before apple consumption.

\section{Effect of apple consumption on $\mathrm{H}_{2} \mathrm{O}_{2}$-induced intracellular oxidative species formation}

As shown in Fig. 3, an AP diet led to a significant percentage increase of levels of $\mathrm{H}_{2} \mathrm{O}_{2}$-induced intracellular oxidative 


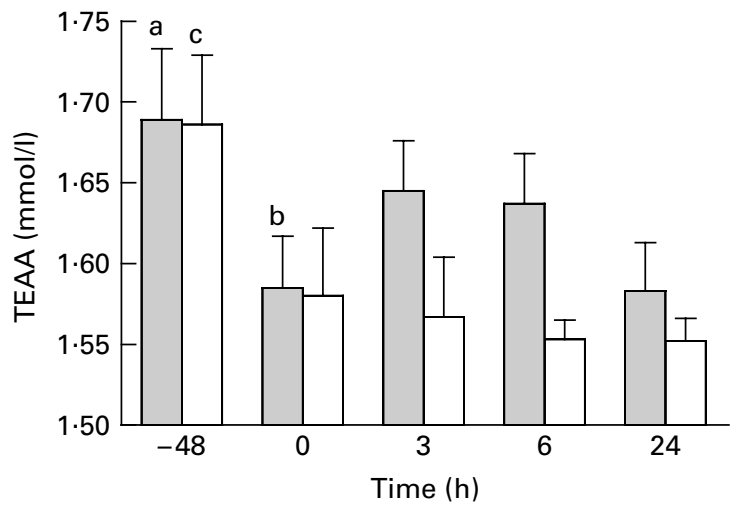

Fig. 2. Effects of AP diet, apples or water consumption on plasma total antioxidant activity. The plasma was subjected to the ABTS radical cation decolorization assay as reported in Materials and methods, and antioxidant capacity was expressed as Trolox equivalent antioxidant activity (TEAA) in $\mathrm{mmol} / \mathrm{l}$. Values are means and standard deviations, $n 6$. The shaded bars indicate apple and the white bars indicate water. (Apple: $\mathrm{a},-48 \mathrm{~h} v$. 0 and $24 \mathrm{~h}, P<0.05$; b, $0 \mathrm{~h}$ v. 3 and $6 \mathrm{~h}, P<0.05$. Water: c, -48 v. $0,3,6$ and $24 \mathrm{~h}, P<0.05)$.

species (apple-assigned subjects, 22.03 (SD 4.02) \% (-48h) v. $34.96(\mathrm{SD} 6 \cdot 87) \%(0 \mathrm{~h})$; water-assigned subjects, 23.20 (SD 3.42) \% (-48h) v. 34.00 (SD 4.85) \% (0h); all $P$ $<0.05)$. Whereas ROS levels up to $24 \mathrm{~h}$ after ingestion of water remained similar to those recorded at $0 \mathrm{~h}$, apple consumption was followed by strongly decreased intracellular ROS levels at both $3 \mathrm{~h}(17.20$ (SD 4.02) $\%, P<0.5$ v. $0 \mathrm{~h})$ and $6 \mathrm{~h}(24.04(\mathrm{SD} \mathrm{3.76)} \%, P<0.05$ v. $0 \mathrm{~h})$. Intracellular ROS levels recorded $24 \mathrm{~h}$ after apple consumption turned out to be the same as those recorded at $0 \mathrm{~h}$.

\section{Effect of apple consumption on $\mathrm{H}_{2} \mathrm{O}_{2}$-induced DNA damage in terms of $M N$ frequency}

We first assessed the effects of AP diet followed by ingestion of apples or water on baseline $\mathrm{MN}$ frequency in cultures not exposed to plasma or challenged with $\mathrm{H}_{2} \mathrm{O}_{2}$. Baseline $\mathrm{MN}$ frequencies and the percentage of $\mathrm{BN}$ cells remained similar in

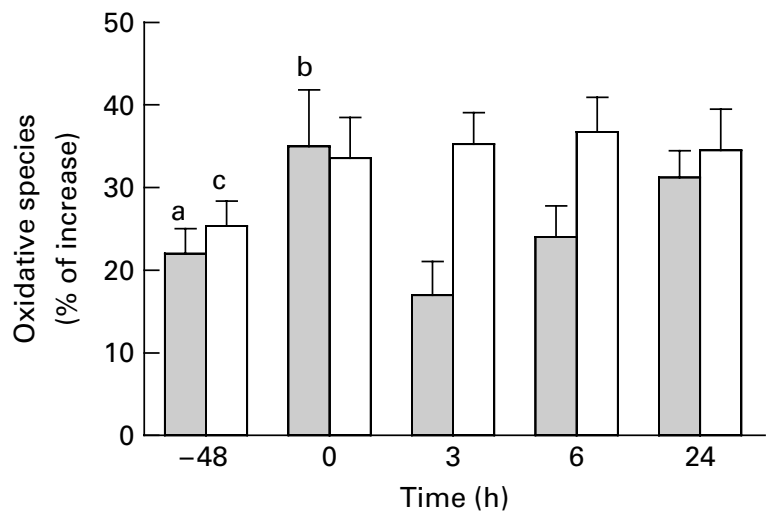

Fig. 3. Effects of AP diet, apples or water consumption on intracellular oxidative species formation in lymphocytes. Levels of intracellular ROS are expressed as the percentage increase of intracellular oxidative species evoked by exposure to $\mathrm{H}_{2} \mathrm{O}_{2}$. Values are means and standard deviations, $n$ 6. The shaded bars indicate apple and the white bars indicate water. (Apple: a, $-48 \mathrm{~h}$ v. 0 and $24 \mathrm{~h}, P<0.05 ; \mathrm{b}, 0 \mathrm{~h}$ v. 3 and $6 \mathrm{~h}, P<0.05$. Water:c, -48 h v. 0, 3, 6 and $24 \mathrm{~h}, P<0.05)$. lymphocytes collected at each experimental time, regardless of apple or water consumption (data not shown). No effects on the percentage of necrotic or apoptotic cells were recorded (data not shown).

We then analysed the effect of apple consumption on peroxide-induced DNA damage, in terms of MN frequency, in cultured lymphocytes exposed to plasma with/without $\mathrm{H}_{2} \mathrm{O}_{2}$ challenge. As reported in Table 2, the data obtained for plasma in the control cultures that were not exposed to $\mathrm{H}_{2} \mathrm{O}_{2}$ after the consumption of apples or water do not suggest any effect on $\mathrm{MN}$ frequency. The overall data for the effects of plasma on $\mathrm{H}_{2} \mathrm{O}_{2}$ challenge indicated an induced significant increase of $\mathrm{MN}$ frequency with respect to the relative controls (cells incubated only with plasma) for all experimental collections.

Fig. 4 illustrates the trend observed following apple or water intake. After an AP diet $(0 \mathrm{~h})$ significant increases in induced MN frequency (obtained after subtraction of the relative control values) were recorded with respect to $-48 \mathrm{~h}$ (apple-assigned subjects, 2.50 (SD 1.87) v. 9.85 (SD 1.87) MN/1000 BN cells, $P<0.05$; water-assigned subjects, $2 \cdot 33$ (SD 1.03) v. 9.50 (SD 1.97) MN/1000 BN cells, $P<0.05$ ).

The results show a significant reduction $(58 \% ; P<0.05)$ in the induced $\mathrm{MN}$ frequency $3 \mathrm{~h}$ after apple intake (4.17 (SD 1.83) MN/1000 BN cells), with a gradual return, $24 \mathrm{~h}$ later (9.33 (SD 1.21) MN/1000 BN cells), toward the values observed before apple consumption $(0 \mathrm{~h})$. MN frequency in cells incubated with plasma from blood collected at $6 \mathrm{~h}$ was intermediate to that observed for plasma collected $3 \mathrm{~h}$ after apple consumption.

The plasma collected after the ingestion of water did not alter MN frequency induced by $\mathrm{H}_{2} \mathrm{O}_{2}$ at 3,6 or $24 \mathrm{~h}$, and the values recorded were similar to those at $0 \mathrm{~h}$.

More interestingly, the increase of the frequency of $\mathrm{MN}$ induced by $\mathrm{H}_{2} \mathrm{O}_{2}$ was significantly influenced by the decrease of the plasma total antioxidant activity $(r=-0.95, P<0.05)$ and by the increase of $\mathrm{H}_{2} \mathrm{O}_{2}$-induced intracellular ROS formation $(r=0 \cdot 88, P<0 \cdot 05) . \mathrm{H}_{2} \mathrm{O}_{2}$ challenge did not influence the proliferation of the lymphocytes, and the $\% \mathrm{BN}$ cells was

Table 2. Effect of plasma collected before and after ingestion of apples or placebo on $M N$ frequency induced by $\mathrm{H}_{2} \mathrm{O}_{2}$ in human lymphocytes $(n 6)$

(Mean values and standard deviation)

\begin{tabular}{|c|c|c|c|c|c|}
\hline & \multirow[b]{3}{*}{ Treatment } & \multicolumn{2}{|c|}{ Apples } & \multicolumn{2}{|c|}{ Water } \\
\hline & & \multicolumn{2}{|c|}{$\begin{array}{l}\mathrm{MN} / 1000 \mathrm{BN} \\
\text { cells }\end{array}$} & \multicolumn{2}{|c|}{$\begin{array}{c}\mathrm{MN} / 1000 \mathrm{BN} \\
\text { cells }\end{array}$} \\
\hline & & Mean & SD & Mean & SD \\
\hline \multirow[t]{2}{*}{$-48 h$} & Plasma & 6.83 & 0.98 & 6.83 & 0.75 \\
\hline & Plasma $+\mathrm{H}_{2} \mathrm{O}_{2}$ & $9 \cdot 33^{*}$ & $2 \cdot 25$ & $9 \cdot 17^{*}$ & 0.98 \\
\hline \multirow[t]{2}{*}{$\mathrm{Oh}$} & Plasma & 7.00 & $1 \cdot 10$ & $7 \cdot 33$ & 1.03 \\
\hline & Plasma $+\mathrm{H}_{2} \mathrm{O}_{2}$ & $16 \cdot 83^{*}$ & 3.13 & $16 \cdot 67^{\star}$ & $2 \cdot 42$ \\
\hline \multirow[t]{2}{*}{$3 \mathrm{~h}$} & Plasma & 7.67 & 1.03 & 7.50 & 0.84 \\
\hline & Plasma $+\mathrm{H}_{2} \mathrm{O}_{2}$ & $11 \cdot 30^{*}$ & 2.56 & $15 \cdot 50^{*}$ & 3.67 \\
\hline \multirow[t]{2}{*}{$6 \mathrm{~h}$} & Plasma & $7 \cdot 50$ & 1.22 & 7.50 & 0.55 \\
\hline & Plasma $+\mathrm{H}_{2} \mathrm{O}_{2}$ & $13 \cdot 00^{*}$ & 3.29 & $16 \cdot 50^{*}$ & 1.76 \\
\hline \multirow[t]{2}{*}{$24 \mathrm{~h}$} & Plasma & 7.33 & 1.02 & 7.83 & 0.98 \\
\hline & Plasma $+\mathrm{H}_{2} \mathrm{O}_{2}$ & $16 \cdot 50^{*}$ & 1.76 & $18 \cdot 00^{*}$ & 1.55 \\
\hline
\end{tabular}

MN, micronuclei.

*Significantly higher than the corresponding plasma value, $P<0.05$. 


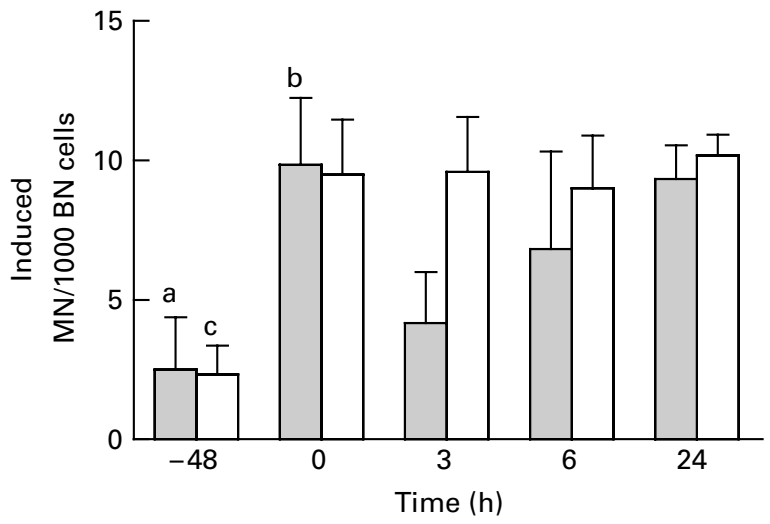

Fig. 4. Effects of plasma collected before and after consumption of apples or water on $\mathrm{MN}$ frequency induced by $\mathrm{H}_{2} \mathrm{O}_{2}$. Results were calculated for each experimental time using the formula: $\mathrm{MN} / 1000 \mathrm{BN}$ in lymphocytes incubated in plasma with $\mathrm{H}_{2} \mathrm{O}_{2}$ subtracted from $\mathrm{MN} / 1000 \mathrm{BN}$ in lymphocytes incubated in plasma without $\mathrm{H}_{2} \mathrm{O}_{2}$. Values are means and standard deviations, $n 6$. The shaded bars indicate apple and the white bars indicate water. (Apple: a, -48 h v. 0,6 and $24 \mathrm{~h}, P<0.05$; b, 0 h $v .3 \mathrm{~h}, P<0.05$. Water:,$-48 \mathrm{~h} v$. $0,3,6$ and $24 \mathrm{~h}, P<0.05)$.

similar among all the experimental conditions investigated (data not shown). No significant difference in the percentage of necrotic or apoptotic cells was observed after intake of apples or water (data not shown).

\section{Discussion}

Several studies suggest that apples might exert beneficial effects on human health due to their phytochemical content (Fang et al. 2002; Hassimoto et al. 2005). This singledosing crossover study highlights, for the first time to our knowledge, the ability of unpeeled whole apple intake to restore the antioxidant plasma activity and to confer resistance to lymphocytes against oxidative DNA injury in humans.

Human intervention trials are important tools to identify the antioxidant activities of different foods and their biological effects on humans. Single-dosing crossover studies are adequate as inter-individual variation can be minimized. This type of study design has also been applied by other authors to assess the antioxidant activity of other fruits or drinks (Fenech et al. 1997; Collins et al. 2001). The inclusion of a placebo group (which can be used in studies with supplements) is not feasible for logistic reasons when foods such as fruit or vegetables are tested (Moller \& Loft, 2002; Hoelzl et al. 2005). Human trials also pose the problem of the compliance of the study population in consuming the food selected in large quantities. In our study, we decided to use an apple homogenate to allow an easy and quick intake of fresh unpeeled apples $(600 \mathrm{~g})$ by the six volunteers enrolled in the study. Furthermore, it has been demonstrated that apple homogenate keeps the antioxidant properties (Campanella et al. 2003).

Apple fruit is a complex mixture containing a variety of potential beneficial compounds, the biological effect of which is dependent on a number of factors, such as bioavailability and the interaction of the various antioxidant compounds. Quercetin is the main bioavailable flavonoid, with a plasma level about $90 \mathrm{ng} / \mathrm{ml}$ at $2.5 \mathrm{~h}$ after intake of apple fruit, and it is more concentrated in the peel than in the pulp
(Gugler et al. 1975; Hollman et al. 1995, 1997). Apples also contain rutin and other glycosides (Manach et al. 2005). Also the fructose content has been proven to increase the antioxidant capacity of apples in humans (Lotito \& Frei, 2004a). The superior antioxidant activity of apples with respect to the sum of the antioxidant activities of pure compounds has been demonstrated recently, suggesting a synergistic effect among the various phytochemical compounds (Vanzani et al. 2005).

Consistent with the observations of a significant decrease in blood resistance to free radicals in healthy individuals eating less than one serving of fruit per day (Lesgards et al. 2002; www.who.int/), our study shows that $2 \mathrm{~d}$ of an AP diet can lead to a significant impairment of plasma antioxidant capacity. The observed decline in plasma antioxidant activity correlates with an increased intracellular generation of ROS by an ex vivo exposure to $\mathrm{H}_{2} \mathrm{O}_{2}$. The antioxidant effects of apple consumption are transient, with a maximum at $3 \mathrm{~h}$ after ingestion. A similar effect of the antioxidant activity of plasma after consumption of apples was also found by Hollman et al. (1997) and Lotito \& Frei (2004b). These data confirm the important role of repeated intake of apples for maintaining a balance between free radical production and antiradical defences in humans (Ko et al. 2005). This hypothesis is supported by the bioavailability of quercetin after apple consumption, which showed a long half-life of elimination, suggesting that repeated consumption of apples will cause accumulation of quercetin in blood (Holman et al. 1997).

Recently, it has been suggested that total plasma antioxidant activity could partly reflect the urate present in plasma (Halliwell, 2003). A flavonoid and urate antioxidant interplay in plasma oxidative stress has been demonstrated (Filipe et al. 2001). In particular, preservation of endogenous urate by quercetin correlated negatively with the formation of free malondialdehyde induced by copper, indicating that quercetin protects the hydrophilic antioxidant capability of plasma. The protection of plasma urate levels by quercetin and the antioxidant synergy between flavonoids and urate may contribute to the beneficial effects attributed to flavonoids. Although we have not measured plasma urate levels, the slight $(\sim 4 \%)$, but significant increase in plasma total antioxidant activity could reflect this synergy between urate levels and apple flavonoids.

The hydrogen peroxide challenge provided the opportunity to assess whether substances in the plasma collected after different diet conditions could quench the potential DNAdamaging effect of the generated ROS. Moreover, incubation with the plasma prior to challenge allowed potential exchange of metabolites between cells and plasma. Our results indicate that a $48 \mathrm{~h}$ AP diet is sufficient to increase the susceptibility of human lymphocytes to genetic damage, as shown by the main increase in $\mathrm{MN}$ frequency induced in vitro by $\mathrm{H}_{2} \mathrm{O}_{2}$ recorded at the end of the diet. This is in line with other studies indicating that a low (or lack of) consumption of fruit can alter the equilibrium status of the pro-oxidant/antioxidant system in cells, causing a pronounced impairment of cellular metabolism and significant damage to tissues (Kim et al. 2003). The ingestion of apple fruit restored the antioxidant defence system in all the volunteers: both plasma and lymphocytes obtained from the six subjects are able to reduce the in vitro genotoxic effects of $\mathrm{H}_{2} \mathrm{O}_{2}$. This phenomenon is associated with both the increase of plasma total antioxidant activity and the decrease of induced intracellular oxidative species formation. 
In conclusion, although our investigation does not allow us to establish the separate contributions of different dietary components to the potential antioxidant effect of apple, the overall results confirm that the consumption of whole apple provide a useful dietary source of active scavengers to protect cells and tissues from oxidative stress and related DNA injury. However, a larger investigation with more volunteers will be required to confirm the observed effects. From both a clinical and a public health prospective, our findings also highlight the importance and utility of the dietary survey programme recommending a regular intake of fruit and vegetable (e.g. the 'five a day programme') to counteract the effect of ROS and to gain health benefit (Cox et al. 1998).

\section{Acknowledgements}

This study was supported by grants from Ministero dell' Istruzione, Università, Ricerca (MIUR ex 60\%); Ministero delle Politiche Agricole, Alimentari, Forestali; Fondazione del Monte di Bologna e Ravenna (Italy).

\section{References}

Ames BN, Gold LS \& Willett WC (1995) The causes and prevention of cancer. Proc Natl Acad Sc USA 92, 5258-5265.

Art IC, Hollman PC, Feskens EJ, Bueno de Mesquita HB \& Kromhout D (2001) Catechin intake and associated dietary and lifestyle factors in a representative sample of Dutch men and women. Eur J Clin Nutr 55, 76-81.

Bazzano LA, He J, Ogden LG, Loria CM, Vupputuri S, Myers L \& Whelton PK (2002) Fruit and vegetable intake and risk of cardiovascular disease in US adults: the first National Health and Nutrition Examination Survey Epidemiologic Follow-up Study. Am J Clin Nutr 76, 93-99.

Block G, Patterson B \& Subar A (1992) Fruit, vegetables, and cancer prevention: a review of the epidemiological evidence. Nutr Cancer 18, $1-29$.

Boyer J \& Liu RH (2004) Apple phytochemicals and their health benefits. Nutr $J$ 3, 1-15.

Campanella L, Bonanni A, Favero G \& Tomassetti M (2003) Determination of antioxidant properties of aromatic, olives and fresh fruit using an enzymatic sensor. Anal Bioanal Chem 376, 467-475.

Collins AR \& Ferguson LR (2004) Nutrition and carcinogenesis. Mutat Res 551, 1-8.

Collins AR, Olmedilla B, Southon S, Granado F \& Duthie SJ (1998) Serum carotenoids and oxidative DNA damage in human lymphocytes. Carcinogenesis 19, 2159-2162.

Collins BH, Horsà A, Hotten PM, Riddoch C \& Collins AR (2001) Kiwifruit protects against oxidative DNA damage in human cells and in vitro. Nutr Cancer 39, 148-153.

Cox DN, Anderson AS, Reynolds J, McKellar S, Lean ME \& Mela DJ (1998) Take five, a nutrition education intervention to increase fruit and vegetables intakes: impact on consumer chose and nutrient intakes. Br J Nutr 80, 123-131.

Crott JW \& Fenech M (1999) Effects of vitamin C supplementation on chromosome damage, apoptosis and necrosis ex vivo. Carcinogenesis 20, 1035-1041.

Duthies SJ, Ma A, Ross MA \& Collins AR (1996) Antioxidant supplementation decreases oxidative DNA damage in human lymphocytes. Cancer Res 56, 1291-1295.

Eberhardt M, Lee CY \& Liu RH (2000) Nutrition: antioxidant effect of fresh apples. Nature 405, 903-904.
Fang Y, Yang S \& Wu G (2002) Free radicals, antioxidants, and nutrition. Nutrition 18, 872-879.

Fenech M, Crott JW, Turner J \& Brown S (1999) Necrosis, apoptosis, cytostasis and DNA damage in human lymphocytes measured simultaneously within the cytokinesis-block micronucleus assay: description of the method and results for hydrogen peroxidase. Mutagenesis 14, 605-612.

Fenech M \& Morley AA (1985) Measurement of micronuclei in lymphocytes. Mutat Res 147, 29-36.

Fenech M, Stockley C \& Aitken C (1997) Moderate wine consumption protects against hydrogen peroxide-induced DNA damage. Mutagenesis 12, 289-296.

Filipe P, Lança V, Silva JN, Morlière P, Santus R \& Fernandes A (2001) Flavonoids and urate antioxidant interplay in plasma oxidative stress. Mol Cell Biochem 221, 79-87.

Galati G \& O'Brien PJ (2004) Potential toxicity of flavonoids and other dietary phenolics: significance for their chemopreventive and anticancer properties. Free Radic Biol Med 37, 287-303.

Gallus S, Talamini R, Giacosa A, Montella M, Ramazzotti V, Franceschi S, Negri E \& Lavecchia C (2005) Does an apple a day keep the oncologist away? Ann Oncol 16, 1841-1844.

Graziani G, D’Argenio G, Tucillo C, Loguercio C, Ritieni A, Morisco F, Del Vecchio Blamco C, Fagliano V \& Romano M (2005) Apple polyphenol extracts prevent damage to human gastric epithelial cells in vitro and to rat gastric mucosa in vivo. Gut 54, 193-200.

Gugler R, Leschik M \& Dengler HJ (1975) Disposition of quercetin in man after single oral and intravenous doses. Eur J Clin Pharmacol 9, 229-234.

Halliwell B (2003) Health benefits of eating chocolate? Nature 426, 787-788.

Hassimoto NMY, Genovese MY \& Lajolo FM (2005) Antioxidant activity of dietary fruit, vegetables and commercial frozen fruit pulps. J Agric Food Chem 53, 2928-2935.

Hertog MG, Feskens EJ, Hollman PC, Katan MB \& Kromhout D (1993) Dietary antioxidant flavonoids and risk of coronary heart disease: the Zutphen Elderly Study. Lancet 342, 1007-1011.

Hertog MG, Kromhout D, Aravanis C, et al. (1995) Flavonoid intake and long-term risk of coronary heart disease and cancer in the seven countries study. Arch Intern Med 155, 381-386.

Hoelzl C, Bichler J, Ferk F, Simic T, Nersesyan A, Elbling L, Ehrlich V, Chakraborty A \& Knasmuller S (2005) Methods for the detection of antioxidants which prevent age related diseases: a critical review with particular emphasis on human interventions studies. J Physiol Pharmacol 56, 49-64.

Hollman PCH, Devries JHM, Vanleeuwen SD, Mengelers MJB \& Katan MB (1995) Absorption of dietary quercetin glycosides and quercetin in healthy ileostomy volunteers. Am J Clin Nutr 62, 1276-1282.

Hollman PCH, Van Trijp JMP, Buysman NCP, Gaag MS, Mengelers MJB, de Vries JHM \& Katan MB (1997) Relative bioavailability of the antioxidant flavonoid quercetin from various foods in man. FEBS Lett 418, 152-156.

Hrelia P, Tarozzi A \& Cantelli Forti G (2003) Diet and risk of cancer. Lancet 361, 258.

Jacobson JS, Melissa DB, Wang LW, Wang Q, Agarwal M, Norkus E, Singh VN, Young TL, Yang D \& Santella RM (2000) Effects of a 6-month vitamin intervention on DNA damage in heavy smokers. Cancer Epidemiol Biomarkers Prev 9, 1303-1311.

Kim HY, Kim OH \& Sung MK (2003) Effects of phenol-rich diets on blood markers of oxidative stress, and urinary excretion of quercetin and kaempferol in healthy volunteers. Am Coll Nutr 22, 217-223.

Knekt P, Jarvinen R, Reunanen A \& Maatela J (1996) Flavonoid intake and coronary mortality in Finland: a cohort study. $\mathrm{Br} \mathrm{Med}$ J 312, 478-481.

Knekt P, Kumpulainen J, Jarvinen R, Rissanen H, Heliovaara M, Reunanen A, Hakulinen T \& Aromaa A (2002) Flavonoid intake and risk of chronic diseases. Am J Clin Nutr 76, 560-568. 
Ko SH, Choi SW, Ye SK, Cho BL, Kim HS \& Chung MH (2005) Comparison of the antioxidant activities of nine different fruits in human plasma. J Med Food 8, 41-46.

Lesgards JF, Durand P, Lassarre M, Stocker P, Lesgards G, Lanteaume A, Prost M \& Leucher-Micher MP (2002) Assessment of lifestyle effects on the overall antioxidant capacity of healthy subjects. Environ Health Perspect 110, 479-486.

Lotito SB \& Frei B (2004a) The increase in human plasma antioxidant capacity after apple consumption is due to the metabolic effect of fructose on urate, not apple-derived antioxidant flavonoids. Free Radic Biol Med. 37, 251-258.

Lotito SB \& Frei B (2004b) Relevance of apple polyphenols as antioxidants in human plasma: contrasting in vitro and in vivo effects. Free Radic Biol Med 36, 201-211.

Manach C, Williamson G, Morand C, Scalbert A \& Rémésy C (2005) Bioavailability and bioefficacy of polyphenols in humans. I Review of 97 bioavailability studies. Am J Clin Nutr 81, 230S-242S.

Moller P \& Loft S (2002) Oxidative DNA damage in human white blod cells in dietary antioxidant intervention studies. Am J Clin Nutr 76, 303-310.

Omenn GS, Goodman GD \& Hammar S (1996) Risk factors for lung cancer and for intervention effects in CARET, the beta-carotene and retinol efficiency trial. J Natl Cancer Inst 88, 1550-1559.

Peto R, Doll R, Buckley JD \& Sporn MB (1981) Can dietary betacarotene materially reduce human cancer rates? Nature 290, 201-208.
Re R, Pellegrini N, Proteggente A, Pannala A, Yang M \& Rice-Evans C (1999) Antioxidant activity applying an improved ABTS radical cation decolorization assay. Free Radic Biol Med 26, $1231-1237$.

Rosenkranz AR, Schmaldienst S, Stuhlmeier KM, Chen W, Knapp W \& Zlabinger GJ (1992) A microplate assay for the detection of oxidative products using $2^{\prime}, 7^{\prime}$-dichlorofluorescin-diacetate. $J$ Immunol Methods 156, 39-45.

Scalbert A, Manach C, Morand C \& Remesy C (2005) Dietary polyphenols and the prevention of diseases. Crit Rev Food Science Nutr 45, 287-306.

Steinmetz KA \& Potter JD (1996) Vegetables, fruit and cancer prevention: a review. J Am Diet Assoc 96, 1027-1039.

Tarozzi A, Marchesi A, Cantell Forti G \& Hrelia P (2004) Coldstorage affects antioxidant properties of apples in Caco-2 cells. J Nutr 134, 1105-1109.

Terry P, Terry JB \& Wolk A (2001) Fruit and vegetable consumption in the prevention of cancer: an update. J Intern Med 250, 280-290.

Vanzani P, Rossetto M, Rigo A, Vrhovsek U, Mattivi F, D'Amato E \& Scarpa M (2005) Major phytochemicals in apple cultivars: contribution to peroxyl radical trapping efficiency. J Agric Food Chem 53, 3377-3882.

WCRF/AICR (1997) Food, Nutrition and the Prevention of Cancer: A Global Perspective. Washington, DC: WCRF/AICR, www. who.int/dietphysicalactivity/publications/facts/fruit/en/ 